Chapter 2

\title{
Tropical Agricultural Production, Conservation and Carbon Sequesteration Conflicts: Oil Palm Expansion in South East Asia
}

\author{
Minerva Singh and Shonil Bhagwat \\ Additional information is available at the end of the chapter \\ http://dx.doi.org/10.5772/52420
}

\section{Introduction}

\subsection{Biodiversity conservation and agricultural conflicts}

Agricultural expansion remains one of the leading causes of deforestation, biodiversity losses and environmental degradation across the world, especially in the tropics (Angelsen et al., 1999 and Norris, 2008). From 1961 to 1993, the world population increased by 80\% (Goklany, 1998). Due to the rapidly expanding human populations large increases in the supply of agricultural products are required, which may lead to the transformation of many landscapes (including biodiversity-rich tropical rainforests) to agricultural landscapes (Ewers et al., 2009). The quest for further land for agricultural production has already caused significant habitat loss and fragmentation, posing substantial threats to the world's biodiversity, forests and ecosystems (Goklany, 1998). According to Matson and Vitousek (2006), many involved in conservation believe that the twin goals of increasing agricultural production and conservation are fundamentally incompatible. Indeed representatives of developing countries (where the tropical forests and majority of the world's biodiversity reside) argue that their developmental needs are partially met by deforestation, since it provides arable land and timber export revenues (Leplay et al., 2010). Further, agricultural revenues accrued from cultivating plantation crops, such as timber, palm and coffee, are significant drivers of deforestation in many parts of the tropics (Kaimowitz and Angelsen, 1998).

Agricultural expansion is often accompanied by significant reductions in tree cover, fallow vegetation, habitat diversity and forest connectivity. Habitat loss and modification are considered to be among the most important drivers of species loss worldwide (Pimm and Raven 2000). Conservative estimates of the effects of anthropogenic land-use changes on global 
breeding bird populations, from a global level meta-analysis, indicate that they have caused losses of between a fifth and a quarter of pre-agricultural bird numbers, across a wide range of temperate and tropical land-use types (Gaston et al., 2003). Large-scale deforestation is also a significant driver of habitat fragmentation, i.e. breaking up of formerly contiguous habitat areas (Laurance and Peres, 2006). Forest fragmentation in turn increases the susceptibility of habitats to edge effects, isolation and disruption of vital ecological processes, followed by species losses from individual forest fragments (Lovejoy, 1986). Forest fragmentation also reduces the ability of forest-dependent species such as understory birds, herbivorous insects and dung beetles to transverse the landscape to reach more suitable habitats (Laurance et al., 2011). Thus, habitat loss, modification and fragmentation synergistically drive biodiversity losses (Hilty et al., 2006).

At a regional level, Singapore represents an extreme case of habitat loss, with a loss of $95 \%$ of its primary rainforest. This extreme habitat loss is correlated with high rates of species losses at all taxonomic levels. Extinction rates have been substantially higher for forest specialists (33\%) than for species that can persist in open/modified habitats and forest edges $(7 \%)$. However, they have been highest for highly habitat-specific taxa, e.g. $67 \%$ and $59 \%$ for habitatspecific birds and mammals, respectively, in Singapore (Brook et al., 2003).' Note, we have deleted the references to 'the island', because Singapore consists of 63 islands, and it is not clear whether you mean the main island or all the islands. Alternatively, you could clarify whether you mean the main islands or the islands generally. There have been considerable efforts to protect biodiversity in reserves and parks, but many of these refuges are small, fragmented, isolated or poorly protected (Harvey et al., 2008). Besides having inadequate dimensions, most protected areas are embedded within agricultural landscapes, and the buffer zones are inadequate to alleviate effects of fragmentation, contamination by agrochemicals, hunting and unsustainable or illegal logging (DeFries et al. 2005).

Biodiversity conservation in many parts of the tropics is threatened by rapid habitat loss and destruction (Sodhi et al., 2004). South East Asia, which hosts four biodiversity hotspots, is especially vulnerable and it is estimated that $42 \%$ of the region's species could be extinct by 2100 (Sodhi and Brooks, 2006). In recent decades, in addition to swidden agriculture, rapid urbanization and timber logging, the expansion of oil palm monocultures has been one of the most significant drivers of deforestation and habitat loss in South East Asia (Corlett and Primack, 2008) and other tropical countries. The coverage of oil palm plantations in Indonesia and Malaysia in 2008 is illustrated in Figure 1.

From figure 1 it can be seen that the area under oil palm plantations has risen significantly since 1990 and this expansion is a major driver for forest loss. The rapid growth of the oil palm industry can be attributed to its uses, which include food products, and other consumer goods such as cosmetics, industrial lubricant and biofuels (Corley \& Tinker 2003). The demand for vegetable oil based biofuel (such as oil palm based biodiesel) is expected to rise exponentially over the coming decades. This in turn is expected to cause an increase in forest loss as natural forests are removed to make way for oil palm monocultures (Butler, 2007). This paper presents an overview of the impact of oil palm plantations on biodiversity and carbon storage. Subsequently, the paper describes the role of human modified landscapes 
on conservation of biodiversity and carbon stocks. Finally, the paper provides a detailed overview and description of the different strategies and landscape configurations that may allow for the reconciliation of conservation priorities with oil palm expansion.

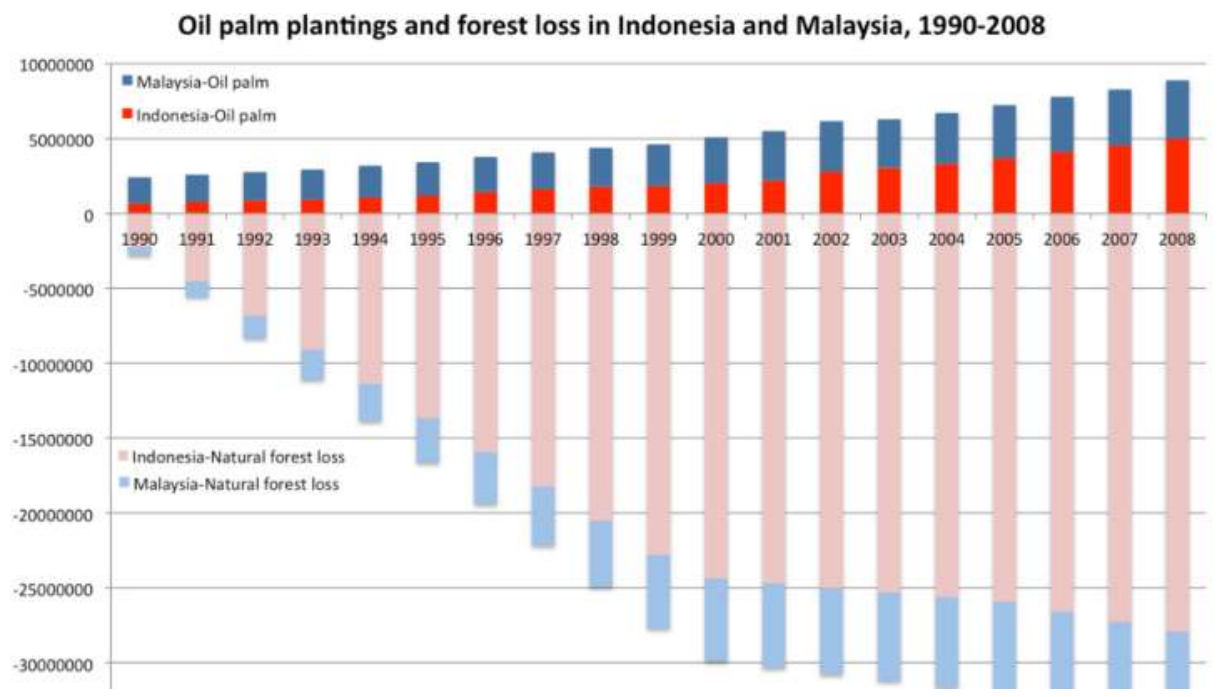

Figure 1. Total forest covered by oil palm plantations, and hence losses of natural forests, in Indonesia and Malaysia (Mongabay, 2012)

\section{Oil palm expansion and associated biodiversity \& carbon storage challenges}

In recent decades, oil palm has become one of the most rapidly expanding crops in the world (Koh \& Wilcove 2007) and occupies 13.8 million hectares in the tropics (FAO, 2009). The rapid growth of oil palm cultivation can be attributed to its value as both a source of food and as raw material for various consumer products, such as cosmetics, industrial lubricants and biofuels (Corley \& Tinker 2003). This rapid oil palm monoculture expansion has been taking place at the cost of primary forests in the tropics (Corley, 2009).

In Indonesia and Malaysia, in the last 20 years deforestation has been driven by expansion of agricultural plantations, especially oil palm monocultures. The replacement of natural forest cover with oil palm monocultures has had detrimental effects on the regional biodiversity. The plantations support less biodiversity than the primary forests or even disturbed and logged forests they replace (Fitzherbert et al., 2008). The lower biodiversity value of oil palm monocultures can be attributed to the absence of major structurally complex components of forest vegetation, including forest trees, lianas and epiphytic orchids (Danielsen et al. 2009). Owing to the lack of the structurally complex flora, oil palm monocultures support less than half the 
vertebrate species found in the natural forests they replace (Persey and Anhar, 2010). An early exploration of these phenomena examined the impact of converting primary lowland forests to logging concessions and oil palm plantations in Sumatra on birds, primates, squirrels, tree shrews and bats (Danielsen and Heegaard (1995). Logging reportedly caused no change in the abundance of primate groups, squirrels and tree shrews, but was associated with a $38 \%-50 \%$ decline in the species richness of bats, while conversion of primary lowland forests to oil palm plantations led to species-poor and less diverse animal communities with fewer specialized species. For instance, only 5\%-10\% of primary forest bird species were recorded (and no mammalian species apart from one primate species) in oil palm plantations.

These findings have been corroborated by recent research focussing on the impact of converting primary forest to oil palm plantations on various species. Across all taxa, only $15 \%$ of species recorded in primary forest were found in oil palm plantations in a study by Fitzherbert et al. (2008). However, the ability of oil palm monocultures to support biodiversity varies across different taxa.

In Malaysia, primary forests support up to 80 mammalian species, while disturbed forests provide habitats for about 30 mammal species and oil palm plantations only support up to 12 species (WWF 2012, Clay (2004)). Corroborative research by Maddox et al. (2007) indicates that oil palm monocultures provide poor habitats for most endangered terrestrial mammal species of South East Asia. Orang-utans are a critically endangered mammal species, restricted to the islands of Sumatra and Borneo. In the recent past, expanding oil palm estates have encroached on their major habitat, the primary lowland forests, and this habitat loss has been associated with sharp decline in their population (Friends of the Earth, 2009). Further, most endangered species, including the iconic Sumatran tiger, tapirs and clouded leopard have not been detected in oil palm plantations. In addition, some species (including deer, macaques and pangolins) have shown a limited tolerance for oil palm plantations (Maddox et al., 2007).

Fukuda et al. (2009) examined effects of land use change on the diversity and distribution of bat species in an intact lowland Dipterocarp forest and surrounding land of modified use types, including secondary forests, orchards and oil palm monocultures. The intact lowland forest had the highest species diversity, and many of the specialist species such as frugivorous and insectivorous bats were absent from oil palm plantations. Oil palm plantations and orchards were only able to provide food sources for three megachiropteran species, and even these species displayed a preference for primary and secondary forests (Fukuda et al., 2009). In addition, Sheldon et al. (2010) found that only between 5\% and 53\% of bird species recorded in Bornean primary forest were also present in nearby oil palm plantations. Similarly, Phillipps and Phillipps (2010) reported that lowland primary forests in Borneo support more than 220 habitat specialist (often endemic and vulnerable) birds, while oil palm plantations support less than a dozen bird species, most of which are generalists? Conversion of primary forests and logged forests to oil palm plantations has also reportedly decreased the species richness of forest birds in Peninsular Malaysia, by $77 \%$ and $73 \%$, respectively (Peh et al., 2006). Similar trends in bird species population declines have been observed elsewhere in the world. Notably, in Thailand, conversion of forests to rubber and oil palm plantations has resulted in a $60 \%$ decline in bird species richness, with insectivorous and frugivorous birds declining more 
rapidly than omnivorous birds (Aratrakorn et al., 2006). Furthermore, bird communities in the oil palm and rubber plantations are reportedly extremely similar. The results confirm that a high proportion of species formerly present in the region are unable to adapt to conversion of forest to oil palm and rubber plantations, resulting in large losses of bird species and the replacement of species with high conservation status by those with extensive ranges and low conservation status.

The species losses have not been restricted to birds. For instance, analyses by Koh and Wilcove (2007) indicate that conversion of primary forests and logged forests to oil palm plantations has decreased species richness of forest butterflies by $83 \%$ and $79 \%$, respectively, in South East Asia. Further, Fayle et al. (2010) found that conversion of lowland forests to oil palm plantations in Sabah (Malaysia) causes a $64 \%$ reduction in ant species richness. Monoculture plantations such as those of oil palm also have much lower species diversity of dung beetles than primary or even logged forests (Chung et al., 2000). Similar trends in the diversity of insect species across different land use types have also been observed elsewhere in the world. For example, Barlow et al. (2007) surveyed dung beetles across different land use types, including Eucalyptus plantations, and found that dung beetle communities have very low species diversity in plantations. Furthermore, the depletion of dung beetle abundance is likely to have detrimental consequences for the maintenance of ecosystem services associated with them. Dung beetles have high ecological importance and are tightly linked with mammal communities (Edwards et al., 2011). Hence any alteration in their community structure can have a domino effect on higher taxonomic groups. Turner and Foster (2009) found that conversion of primary forests and logged forests to oil palm plantations in Malaysia also detrimentally affects the abundance of arthropods at all levels of the forest ecosystem. In another survey, of moth population distributions and diversity in Danum, Sabah, $67 \%$ of the species recorded in primary forest were not detected at oil palm sites and adjacent, disturbed forest (Chey, 2006). The results showed that biodiversity loss (using moths as indicator species) was most significant in oil palm plantations, the most common form of forest conversion in Sabah.

Hence, on the basis of evidence presented in the literature cited above, it may be inferred that oil palm plantations tend to have less taxonomically diverse species assemblages than more diverse habitats such as logged forests. These monocultures are poor substitute habitats for most tropical forest species, particularly those of high conservation concern, such as vulnerable, endemic or range-restricted species. Plantation assemblages are typically dominated by a few generalists (e.g. macaques and dusky munias), alien invasives (e.g. crazy ants), pests (e.g. rats), and their predators (e.g. pythons and barn owls) (Sodhi et al., 2010). This has been attributed to the fact that the extreme disturbance that follows conversion to oil palm plantation has a significantly negative impact on the flora and fauna of the area.

In addition to having detrimental effects on biodiversity, oil palm expansion also contributes to carbon emissions in South East Asia (Koh et al., 2011). Forest conversion to oil palm monoculture causes a net release of approximately $650 \mathrm{Mg} \mathrm{CO}_{2}$ equivalents per hectare, and emissions resulting from peat forest conversion are even higher due to the decomposition of drained peat and consequent release of greenhouse gases (GHGs; Germer and Sauerborn, 2008). This conversion in turn creates a "biofuel carbon debt" by releasing 
17 to 420 times more $\mathrm{CO}_{2}$ than the annual GHG reductions that these biofuels would provide by displacing fossil fuels (Fargione et al., 2008). Research by Danielsen et al. (2009) indicates that it could take between 75-93 years for carbon emissions saved from the use of biofuels to compensate for the carbon released by forest conversion. $\mathrm{CO}_{2}$ emissions from conversion of peat swamp forest, in particular, are far greater than gains from substitution of fossil fuels with palm oil (Hooijer et al., 2006).

While the carbon sequestration and conservation value of old growth and undisturbed primary forests is well established, less than pristine human modified landscapes also have considerable conservation and carbon storage potential. Research by Berry et al. (2010) indicates that more than $90 \%$ of the species recorded in primary forests are also present in logged forests. In addition to providing vital habitats for biodiversity, human-modified landscapes (such as logged forests) have significant carbon storage potential. During recovery, Berry et al. (2010) found that logged forest accumulated carbon five times more rapidly than natural forest (1.4 and $0.28 \mathrm{MgC} \mathrm{ha}^{-1}$ year $^{-1}$, respectively), providing significant carbon storage.

Hence, in order to create palm oil monocultures that do not damage local biodiversity and carbon stocks, it is vital to include human modified/degraded landscapes in any conservation program considered for a given area.

\section{Role of human-modified landscapes in biodiversity conservation}

A significant body of literature (discussed in the previous section) indicates that converting land to oil palm plantations has a detrimental effect on most taxa. However, literature also indicates that the marginal and/or degraded habitats often found within or outside palm oil concessions can retain high conservation values. The fate of biodiversity within patches of lowland forests is inextricably linked to the broader landscape context, including how the surrounding agricultural matrix is designed and managed (Wallace et al. 2005). Species are more likely to persist in protected areas that incorporate local environmental heterogeneity, because this provides them with a range of conditions, thereby allowing them to adjust their local distribution in response to environmental change (Gillson and Willis, 2004). Whilst this matrix is rarely of the quality found in protected areas, using the conservation potential of unprotected lands can help overcome many of the shortfalls of the protected area system (Maddox et al., 2007) and combat the effects of habitat loss, fragmentation and edge effects. For instance, selectively logged forests can make important contributions to the conservation of tropical biodiversity, provided that they are managed in a way that maintains environmental heterogeneity (Hamer et al., 2003).

There are also other land use types that can counter the threats oil palm monocultures pose to biodiversity. While intensive oil palm monocultures offer few biodiversity conservation benefits (Koh, 2008), other plantation systems, such as cocoa agroforests and mixed fruit orchards, may provide valuable habitats (Hartley 2002). This dichotomy may be due to the vegetation structure of monocultures being too simple to support high levels of species diversity, while multi-species plantations (especially those that encompass remnants of native 
vegetation) have much more complex structure, with significant resemblance to primary vegetation (Lindenmayer and Hobbs, 2004). The dichotomy has important implications for both conservation strategies and the design of oil palm plantations, indicating that modified landscapes and new planning strategies may be required to reduce their impacts on local biodiversity (Maddox et al., 2007).

The problems associated with reducing the adverse effects of agricultural expansion on nature are substantial and require urgent attention. Two very different management approaches have been recommended in the literature to address these problems: land sparing, in which farm yields are increased and pressure to convert land for agriculture is reduced (at the potential cost of reducing wildlife populations on farmland); and land sharing/wildlife friendly farming, in which on-farm practises that are benign to wildlife are applied (Balmford et al., 2005).

\subsection{The land sparing approach}

In land sparing, homogeneous areas of farmland are managed to maximize yields, while separate reserves target biodiversity conservation. Land sparing is associated with an island model of modified landscapes, where islands of nature are seen as separate from human activities. The resulting agricultural systems are mostly homogenous and industrial in style, striving for maximum economic efficiency. They commonly rely on high inputs of fertilizers and pesticides, crop diversity is usually low, and individual fields tend to be large (Fischer et al., 2008). Indeed, according to Waggoner (1996), high yields of food crops have to be maintained if mankind is to put aside any land for biodiversity conservation. This arguably makes a compelling argument for land sparing.

Green et al. (2005) have presented a model that identifies the trade-offs involved. According to their research on a range of taxa in developing countries, high yield farming provides a means of allowing more species to persist. In accordance with the model: the abundance of imperilled bird species is reportedly 60-fold lower in fragments and 200-fold lower in oil palm plantations than in primary contiguous forest; retention of forest fragments does not increase bird abundance in adjacent oil palm plantations; and fragments have lower species richness than contiguous forest, with an avifaunal composition that is more similar to that of the plantations than contiguous forest (Edwards et al., 2010). Therefore, from a conservation perspective, any investment in the retention of fragments would be better directed toward the protection of primary contiguous forest. In contrast, censuses of birds in El Trunifo Biosphere reserve, southern Mexico, indicate that shade coffee plantations may have bird diversity levels similar to those of natural forests (Tejeda-Cruz and Sutherland, 2004). However, the coffee agricultural systems and natural forests differ in species composition, notably birds that are highly sensitive to disturbance are more abundant in primary forests. Hence, although coffee agricultural systems may play an important role in maintaining local biodiversity, their promotion as a "silver bullet" may encourage the transformation of primary forests to shade coffee plantations, leading to a loss of forest species. Similarly, in North Borneo there is reportedly little difference in butterfly diversity between primary and logged forests, but marked differences in the composition of butterfly assemblages between the two habitats. Butterfly species with higher shade preferences and narrower geographic distributions are 
particularly adversely affected by logging (Hamer et al., 2003). A similar, earlier survey of butterfly species distribution in Buru, Indonesia, indicated that their species richness and abundance was higher in primary forests than in other land use types. The primary forests also housed endemic species and species whose distribution is restricted to the province (Hill et al., 1995). Dunn (2004) compared the effects of logging and conversion of forest to agriculture or pasture on ant, bird, and lepidoptera species richness by combining data from 34 studies of tropical forests in Africa, Asia and the Americas, finding that forest conversion to agriculture or pasture decreased the species richness of ants and animals overall.

On the basis of the impacts that forest clearance has on the distribution different kinds of taxa, many authors have recommended using land sparing techniques as a way of conserving maximum possible biodiversity. Due to the impacts of forest clearance on the distribution of various taxa, many authors (e.g., Ghazoul et al., 2010) have recommended land sparing strategies to conserve maximum possible biodiversity. Accordingly, studies by Anderson et al. (2009) indicate that achieving both high agricultural production and biodiversity is difficult within a single land management system, and some 'land sparing' is necessary to achieve biodiversity targets. Research by Phalan (2009) in Ghana also indicates that increasing yields on existing croplands may enhance possibilities to spare natural habitats, by reducing the area of land needed for agriculture. According to these authors, the persistence of many species maybe better enhanced by enlarging or maintaining areas of natural forest cover while intensifying production on converted land to ensure that demands for plantation crops (such as oil palm) are met by maximizing yields on unforested land. This view is supported (inter alia) by findings presented by Green et al. (2005) and Balmford et al. (2005) that more bird diversity could be sustained by portioning land between intensive agriculture and wildlife reserves. Thus, although land sparing is a weak strategy, and can only be applied under a limited set of circumstances, it can have positive outcomes for nature conservation (Ewers et al., 2009).

Despite its proposed benefits, the land sparing approach has been heavily critiqued in a body of peer-reviewed literature. Notably, Matson and Vitousek (2006) suggest that intensive agricultural systems may fail to spare land for nature and the high use of agricultural inputs may adversely impact areas downstream from the agricultural farms. Thus, the high use of agro-chemicals, such as fertilizers, which is required for land intensification, could have detrimental effects on biodiversity, although extensive integrated land management could enhance profitability and benefit native vegetation (Moll et al., 2007). In contrast, Polasky et al. (2005) found that biodiversity conservation objectives can potentially be achieved in agricultural landscapes with thoughtful land-use planning. Due to the degree of conflict between conservation and agricultural returns, with the assumption that sensitive species survive only within and economic activity only outside reserves, land-sparing is a much less integrated approach than some options. Further, it does not recognize, or incorporate, the important contributions to the conservation of tropical biodiversity that other land use types, such as selectively logged forests, can make provided that their management maintains environmental heterogeneity (Hamer et al., 2003). 
According to Norris (2008), it is important to recognize that some biodiversity is retained in agricultural landscapes, and that it is the degree of biodiversity retention that we need to understand and effectively manage. In regions such as Indonesia there are relatively few pristine areas and agriculture-forest mosaics now comprise much of the landscape (Koh et al., 2009). In this scenario, given the fragmented nature of most tropical ecosystems, agricultural landscapes should be an essential component of any conservation strategy (Perfecto and Vandermeer, 2010). In this context, we examine an alternative land management option; wildlife friendly farming.

\subsection{Land sharing/wildlife friendly farming}

Estimates suggest that more than half of all species exist principally outside Protected Areas, mostly in agricultural landscapes (Blann, 2006). Such species can be conserved by modifying existing agricultural landscapes through the principles of eco-agriculture and wildlife friendly farming (Scherr and McNeely, 2007).

In wildlife-friendly farming, as opposed to land sparing, conservation and production are integrated within more heterogeneous landscapes (Fischer et al., 2008), but agricultural yields tend to be relatively low (Green et al. 2005). Therefore, a larger land area is typically needed to produce the same agricultural yield. While this leaves less land for permanent preservation, more biodiversity can occur on the "wildlife-friendly" agricultural land itself (Fischer et al., 2008). Wildlife friendly farming systems apply the principle that agricultural landscapes can be designed and managed to host wild biodiversity of many types, with neutral or even positive effects on agricultural production. It may be regarded as an integrated conservation-agriculture strategy, in which biodiversity conservation is an explicit objective of agriculture and rural development, which are explicitly considered in shaping conservation and livelihood strategies (Scherr and McNeely, 2007). For instance, agroforestry systems are important for the livelihood of many families in rural areas of the tropics, especially the humid tropics where most biodiversity hotspots are located. They may also provide critical refuges for wildlife. Hence, wildlife friendly land planning strategies like these should be considered important components of integrated landscape conservation strategies (Perfecto and Vandermeer, 2008).

Harvey et al. (2008) discuss the illustrative case of Mesoamerican biodiversity hotspots, where $80 \%$ of the primary forest has been converted to agricultural landscapes and the survival of endemic species is threatened. The cited authors propose an integrated landscape management strategy, in which conservation and production units within the agricultural matrix are managed jointly for long-term sustainability and agricultural production. While this approach is unlikely to maximize agricultural productivity, traditional small-scale farms can provide both farmer livelihoods and biodiversity conservation (Harvey et al., 2008), since forested and non-forested habitats contribute to biodiversity conservation.Forest fragments, riparian forests, tree plantations and other types of remnant and introduced tree cover serve as habitats for many species, enhance landscape connectivity, and retain potential for forest regeneration and restoration (Chazdon 2003; Harvey et al. 2006a Furthermore, landscapes exploited for various other uses, such as di- 
verse coffee agroforestry (Moguel \& Toledo 1999; Komar 2006), cocoa agroforestry (Rice \& Greenberg 2000; Harvey et al. 2006b ) and traditional agro-ecological land systems, such as organic farming and swidden agriculture (Finegan \& Nasi 2004), also retain high levels of both wild and agricultural biodiversity and offer much greater conservation value than the high-yield intensive agricultural landscapes that are proposed to replace them.

According to Bhagwat et al. (2008), agroforestry systems can alleviate resource use pressure in protected areas, enhance habitats for certain species and improve the connectivity of landscape components. Traditional agroforestry systems such as jungle rubber, shadegrown coffee and cocoa systems in the tropics resemble natural rainforests in many structural respects, and thus have been suggested to be promising wildlife-friendly land use strategies, conserving a significant proportion of tropical rainforest diversity while providing significant economic returns (Schroth et al., 2004). As primary forests shrink, fragment and are reduced to isolated habitat islands in a landscape dominated by agricultural farms/plantations, agroforestry systems could help maintain higher levels of biodiversity both within and outside protected areas. Although it has been correctly noted that agroforestry systems displace natural ecosystems, they offer greater potential for reconciling biodiversity conservation with agricultural production than intensive monocultures (Schroth, 2003).

To illustrate the potential conservation utility of agroforestry systems, For example, jungle rubber gardens of Indonesia are low-input rubber agro-forests that structurally resemble secondary forest and retain high populations of wild species. Beukema et al. (2007) compared the plant and bird diversity in Indonesian jungle rubber agroforestry systems to that in primary forest and rubber plantations. They found that species richness in the jungle rubber systems was slightly higher for terrestrial pteridophytes, similar for birds and lower for epiphytic pteridophytes, trees and vascular plants as a whole than in primary forest. For subsets of 'forest species' of terrestrial pteridophytes and birds, species richness was lower in the jungle rubber systems than in primary forest. These findings show that forest-like land use can be potentially used to support species diversity in an impoverished landscape increasingly dominated by monoculture plantations (Beukema et al., 2007). Similarly, Perfecto et al. (2005) investigated the biodiversity conservation potential of shade-grown coffee systems and concluded that due to the retention of canopy cover such agro-forests can provide both biodiversity conservation and economic returns from agricultural production. According to Harvey, (2007) transformation from near-primary forest to cocoa agroforestry in Sulawesi (Indonesia) has had little effect on overall species richness, but reduced plant biomass and carbon storage by $\approx 75 \%$, and the species richness of forest-using taxa by $\approx 60 \%$. In contrast, increased land use intensity in cacao agroforestry, coupled with a reduction in shade tree cover from $80 \%$ to $40 \%$, has caused only minor quantitative changes in biodiversity and maintained high levels of ecosystem functioning while doubling farmers' net income. Hence, Harvey, (2007) concluded that low-shade agroforestry provides the best available compromise between economic forces and ecological needs. Similarly, Harvey and Villalobos (2007) examined species diversity across various agroforestry systems and concluded that heterogeneous mixed plantations of tree crops such as banana and cocoa are more hospitable to biodiversity than monoculture plantations. Round 
et al. (2006) compared the distributions of birds in a mixed fruit orchard and a nearby isolated forest patch on Khao Luang mountain, southern Thailand, with that in natural forest. They found the orchard was about $75 \%$ as rich in bird species as the forest, and the avifauna in the former was dominated by smaller fugivorous, nectarivorous and widespread generalist species. Sundaic birds contributed $26 \%$ of sightings in the orchard, although understory insectivores were poorly represented. However, while agricultural diversification may assist in restoring modest levels of diversity in areas already degraded or committed to human use, it should not be seen as a substitute for conventional protection of forest and wildlife. Communities in disturbed habitats are known to contain significantly more generalized species than those associated with pristine habitats (Taki and Kevan 2007), hence it is vital to identify the optimal approach for a given scenario.

\section{Land sparing versus wildlife friendly farming choices}

Both land sparing and land sharing approaches have advocates, and pros and cons, raising questions about which, if either, approach should be used. The optimal choice between land sparing and wildlife-friendly farming, or combining the two, to maintain production and biodiversity will differ between landscapes (Hodgson et al., 2010). The choice of which strategy to use could be informed by yield-density relations, which describe relationships between population densities of particular species and agricultural yields. Land sparing is a recommended strategy for species whose populations decline rapidly when their natural intact habitats are converted to low intensity agricultural landscapes. In contrast, wildlife friendly farming may be more appropriate for species whose densities persist even when their intact natural habitats are converted in this manner (Mattison and Norris, 2005).

Instead of taking an either-or approach, Koh et al. (2009) draw on both strategies, advocating the creation of agroforestry zones between high conservation value areas and intensive agricultural plantations (such as palm oil monocultures) to create more heterogeneous landscapes that can benefit both biodiversity and rural communities. However, before selecting any of the aforementioned approaches many other landscape level factors must be taken into account. The landscape considerations that can arise and why they need to be addressed has been illustrated by a comparison of distributions and abundance patterns of multiple species (frogs, bats and dung beetles) between a cloud forest and coffee agroforestry in Mexico (Pineda et al., 2005). The three indicator sets of species considered responded differently to land use change from montane cloud forest to coffee agroforestry. The species richness of frogs in the coffee agroforestry system was just a fifth of that in the cloud forests, and a third of the forest species were recorded in both the forest and the coffee agroforestry system. In contrast, the abundance and diversity of beetle species were higher in the coffee agroforestry system, while the composition of bat species did not significantly differ between the land use types. This variation in species distribution has been attributed to differences in the permeability of different species through the two habitats and their physiological traits. Shaded coffee agroforestry systems form a matrix around remnant patches of the cloud forest, and provide connections between the forest fragments and other habitats in the landscape. 
Although such systems cannot be regarded as substitutes for the primary forest habitats they replace, they can allow the preservation of biodiversity in a fragmented, human-modified landscape (Pineda et al., 2005). Wells et al. (2007) surveyed the species assemblages of small non-volant mammals in three unlogged and three logged forests and compared the species richness, dominance and evenness of small non-volant mammals between these habitats in Sabah, Indonesia. They found species richness and diversity were higher in logged forests, and all common species were present in both habitats. However, closer analysis revealed that while habitat modification did not have a significant effect on the distribution of most of the species it had a profound impact on the rarer species. Rare and specialized species, such as arboreal mammals and Viverridae, were completely missing from logged forest sites. Hence, while the conservation value of logged forests cannot be negated, it can be inferred that the presence of logged forests may not help the conservation and preservation of habitat-specific and rangerestricted species.

These case studies not only illustrate potential configurations of a designer landscape (e.g. a primary forest-coffee agroforestry or primary forest-logged forest system) but also the fact that in order to create a designer landscape, characteristics of the surrounding matrix and the ability of given species to adapt to a modified landscape have to be analysed. Many other landscape elements can also help in the creation of designer landscapes. In addition to structurally complex agroforestry systems, these include small rainforest fragments in agricultural landscapes, high conservation value forests and wildlife corridors (aspects of which are discussed in detail below). However, before deciding which configuration of landscape elements/habitats can help create a designer landscape suitable for achieving a desired set of conservation goals, it is vital to understand the theoretical foundations of designer landscapes.

\section{Theoretical foundations of designer landscapes}

From a biodiversity conservation perspective, maintaining vast areas of unmodified land has been considered to be desirable. However, increasingly biodiversity has to persist, as far as possible, in human-dominated landscapes that have been heavily modified for producing agricultural and forestry commodities. In such a scenario there is widespread evidence that heterogeneous, designer landscapes provide greater biodiversity benefits than intensively managed monocultures (Fischer et al., 2006). For instance, carefully designed landscapes can play important roles in offsetting the negative edge effects of intensive agricultural plantations adjoining patches of native vegetation (Koh et al., 2009).

Fischer et al. (2006) recommend several strategies that are likely to help efforts to maintain diverse species and ecological processes in production landscapes. The most important is maintenance of large patches of native vegetation, because the structural complexity of native vegetation is very important for maintaining vital ecological processes, which in turn are vital for the persistence of biodiversity. They also provide vital habitats for species that cannot persist in the absence of native vegetation. However, maintenance of structural complexity within commodity production landscapes (including designer landscapes) is also vital for 
conserving biodiversity. The key element of this strategy is the "matrix"; the area surrounding patches of native vegetation (Forman, 1995), which significantly influences the withincommunity remnant dynamics (Laurance, 1990). A matrix with complex vegetation structures similar to those of native vegetation supplies a variety of ecosystem benefits, including support for ecological processes, varied habitats for species outside patches of native vegetation or protected areas, shelter, breeding sites, additional food resources and the capacity to recover from disturbance (Chazdon et al., 2009).

"Matrix effects" may also explain why the abundance and richness of species can be maintained in non-forest habitats such as agricultural production systems, logged forests (Barlow et al., 2007) and mixed cropping systems. These modified landscapes successfully provide habitat elements and ecological processes needed for species persistence outside of a primary forest habitat. For instance, as mentioned above, jungle rubber gardens of Indonesia structurally resemble secondary forest and allow wild species of various taxa to persist Beukema et al. (2007). The cited findings, and other examples, illustrate the potential importance of the landscape matrix surrounding primary forest or primary forest patches for enabling species persistence and biodiversity conservation in non-forest habitats. A number of examples illustrate the role landscape matrix surrounding the primary forest patches or primary forests play in enabling species persistence and biodiversity conservation in non-forest habitats.

Oil palm plantations, particularly, can be made wildlife friendly by preserving forest fragments, riparian strips, etc., and/or by providing habitat complexity within them in the form of epiphytes and understory plants (Jackson et al., 2010). These elements can maintain both connectivity of habitats for animal species and vital ecological processes at landscape scale (Bennett, 2003). The following sections discuss some of these landscape configurations, and particularly how they can help the creation of more sustainable oil palm plantations.

\subsection{Biodiversity in small fragmented rainforest patches}

As discussed above, deforestation is occurring at an alarming rate in the tropics, leading to high rates of forest fragmentation, especially in South East Asia (Sodhi et al., 2004), and species losses resulting from these processes have been described as the greatest threats to biodiversity (Myers, 1989). It has been argued that small fragments may become the last refuges of many rainforest species on the brink of extinction, and in areas with little residual rainforest fragments can act as 'seeds' for re-establishing extensive forest (Turner and Corlett, 1996). Thus, since high rates of land conversion coincide with high levels of species richness and endemism, it is imperative to determine the capacity of small forest remnants to support biodiversity.

In a rapid evaluation of butterfly species in a single remaining forest patch in Costa Rica, Daily and Ehrlich (1995) found that even small (20-30 ha), isolated forest fragments retained a large butterfly fauna. This suggests that even heavily managed systems of largely exotic plants (such as agricultural systems) could be designed to serve as corridors for butterflies and perhaps some other groups of organisms and connect separated forest patches. Benedick et al. (2006) evaluated impacts of habitat fragmentation on the species richness and faunal composition of butterflies in tropical rainforests in Sabah, Borneo, considering both $\alpha$ - and $\beta$-diversity patterns 
to assess the relative importance of patch size, isolation and vegetation structure for the diversity and similarity of species assemblages. They concluded that variations among fragments added substantial species diversity to the butterfly assemblage in Bornean rainforests. The reported data indicate that, despite having lower species richness than contiguous primary forest, relatively small and isolated rainforest remnants make substantial contributions to regional diversity. Similar conclusions were drawn by Struebig et al. (2008) from an analysis of the biodiversity value of forest fragments in peninsular Malaysia. They estimated frequencies of insectivorous bat species at seven continuous forest sites and 27 forest fragments, then tested the effects of fragment isolation and area on the abundance, species richness, diversity, composition and nestedness of assemblages, and the abundance of the 10 most common species. The results indicate that while large tracts of contiguous forests are needed to support rare, forest specialist species and their retention should be a high conservation priority, forest fragments also perform vital conservation roles. More specifically, fragments larger than 300 ha appear to contribute substantially to landscape-level bat diversity (retaining comparable diversity to continuous forest), but small fragments (less than 150 ha) also have some conservation value, despite having more variable species composition than either larger fragments or continuous forest.

Small, isolated forest remnants are generally accorded low conservation status and given little protection, consequently they often disappear over time because of continued anthropogenic disturbance. However, the results presented by Struebig et al. (2008) indicate that the conservation value of small forest remnants' contributions to environmental heterogeneity should not be neglected. Similarly, Arroyo-Rodriguez et al. (2009) found small $(<5$ ha) forest patches to be important for the conservation of regional plant diversity in the tropical rainforests of Mexico. Despite their small dimensions, they reportedly contained diverse communities of native plants, including endangered and economically important species. Hence, the conservation and restoration of small patches may be essential for effective preservation of plant diversity in this strongly deforested and unique Neotropical region. Further, Estrada and Coates-Estrada (2002) examined responses of bat species' abundance and distribution to habitat destruction and deforestation by surveying a continuous forest patch, fragments and an agricultural mosaic habitat in Mexico. While most bat species were found in the primary forest patch, the co-occurrence of the three habitats aided conservation of the bats by allowing them to disperse through the landscape. However, a one-size-fits-all approach cannot be applied when trying to include isolated rainforest patches as part of a conservation strategy and results of these studies must be interpreted cautiously.

Research on the impact of forest fragmentation on leaf litter ant communities in Sabah further illustrates its detrimental effect on species abundance and composition. Bruhl et al. (2003) evaluated distributions of these ants in two forest fragments and a contiguous forest patch. The species numbers and diversity recorded in the forest fragments were less than half of those recorded in the primary forest patch. Further, the community composition was also altered by fragmentation. Similar effects, on other species, have been observed elsewhere in the world. Notably in Tanzania, protected areas are increasingly becoming habitat islands in a sea of modified landscapes (such as agricultural fields). This habitat isolation has been correlated 
with mammalian extinctions (Newmark, 1996). Indeed, research by Turner and Corlett (1996) indicates that in nearly all cases of tropical fragmentation there have been losses of local species, most severely for large species and species that have highly specific habitat requirements. These effects have been attributed to forest edge effects, reductions in population size and changes in community structure arising from fragmentation.

In spite of evidence of species currently persisting in isolated forest fragments, possible "extinction debts" must also be considered, i.e. the possibility that some populations may have survived extensive habitat loss but still face extinction owing to a time lag between initial habitat loss and eventual population decline (Cowlishaw, 1999). Nevertheless, the surrounding matrix can ameliorate effects of the isolation of habitat patches much more than can be readily explained by classical theories such as island biogeography theory. Thus, matrix modification may provide opportunities for reducing the isolation of individual primary habitat patches, and thus extinction risks of populations in fragments (Ricketts, 2004). Hence, in addition to other measures, management schemes such as improving the landscape matrix and habitat connectivity, e.g., by incorporating wildlife corridors may make valuable contributions to conservation landscapes, as discussed in the following section.

\subsection{Improving landscape matrices and connectivity}

Bhagwat et al. (2005) examined the diversity of pants, micro-fungi and birds at 58 sites (in 10 forest reserves, 25 sacred groves and 23 coffee plantations) in the Western Ghats, India. They found that the biodiversity in the sacred groves had been influenced by native tree cover in the surrounding landscape (as opposed to patch size), and recommended that the tree-covered landscape matrix should be preserved to conserve this biodiversity This is consistent with earlier findings that the quality of the matrix surrounding forest fragments plays a significant role in population persistence (Fahrig 2001). Further, matrix quality can be improved by maintaining heterogeneous landscapes with a variety of vegetated features.

Horskins (2005) has defined matrix as the landscape elements surrounding a habitat of focal interest (for instance, a primary forest fragment). One such element is a wildlife or biological corridor, described as a linear stretch of habitat, differing in structure and vegetation type to that of the matrix type, linking two habitat patches (such as rainforest patches) that would otherwise be isolated from one another (Laurance, 1990). Wildlife corridors can allow the conservation of species in fragmented habitats by increasing the connectivity between isolated habitat patches and integrating populations into single demographic units. Connecting patches of habitat with corridors has been shown to slow extinction rates of species, and species richness has been preserved for longer periods of time in connected than in disconnected habitat patches (Gilbert et al., 1998). In addition, Laurance and Laurance (1999) showed that linking primary forest patches to a large continuous primary forest provided more habitats for mammalian species and greatly facilitated their movement in Australia. They found the linking of primary forest patches to a large continuous primary forest greatly allowed for movement and habitat for mammals.

Agroforests can also play important roles in expanding habitats for a wide range of species and provide wildlife corridors that can facilitate the movement of species across a given 
landscape (Elevitch, 2004). In addition to supporting native species of plants and animals, agroforestry systems may contribute to the conservation of biodiversity by enhancing the connectivity of populations, communities, and ecological processes in fragmented landscapes. As mentioned above, habitats that can maintain such connectivity across landscapes are commonly referred to as biological or wildlife corridors, and their potential value is further considered below.

\subsection{Wildlife corridors}

Hilty et al. (2006) describe a wildlife corridor as a landscape element that connects two patches of suitable habitat by passing through a matrix of unsuitable habitat. The concept of wildlife corridors emerged from research on habitat fragmentation, and was based on the premise that fragments that are linked by a corridor of similar suitable habitat are likely to have greater conservation value than isolated fragments of similar size and could combat the adverse effects of habitat fragmentation (Diamond 1975). Protection or provision of continuous habitat corridors to link isolates such as nature reserves or old-growth forest patches is seen as more beneficial than retaining individual habitat patches (Bennett, 2003). Indeed, wildlife corridors have been shown to facilitate the migratory movements of birds and mammals (Newmark, 1993), and are currently being proposed as a means of combating the isolation of protected areas in Tanzania (Caro et al., 2009).

Extensive habitats like these provide permeable corridors for species to disperse through landscapes much more readily than through monocultures (Watts et al., 2005). Thus, the presence of wooded corridors and shrub-matrix can make intensive monoculture plantations more hospitable to the presence and dispersal of species, including endemics (Castellon and Sieving, 2006).

\subsection{Riparian margins}

Riparian margins are linear landscape elements that can play vital roles in offsetting the effects of habitat fragmentation and loss (Lees and Peres, 2007). They can support the persistence and dispersal of a wide assemblage of taxa, especially small vertebrate taxa (Lees and Peres, 2007) and bird species (Wild Asia, 2011) by providing structural connectivity. Notably, the ability of riparian margins to allow species dispersal is of vital importance for forest birds, which face severe population decline resulting from fragmentation in tropical countries like Costa Rica. Further, forest specialist bird species also use riparian margins for dispersing through fragmented landscapes (Gillies and St Clair, 2008). As an illustration of the benefits of riparian margins for countering adverse effects of habitat fragmentation, forest birds that depend on army ants for food respond negatively to fragmentation, and disappeared very rapidly when 1 and 1 ha fragments were isolated from contiguous forests in the Brazilian Amazon (Bierregaard et al., 1992 in Bennett (2003)). However, a fragmented patch (2 km long and 100-300 m wide) that remained connected to contiguous forest by a riparian margin retained the same species composition and abundance of understory birds as the continuous forest. The riparian margins were further found to enhance the movement of birds through the fragmented landscape and maintenance of population and species composition (Bennett, 2003). Riparian 
margins also have significant conservation value and serve as buffers against fragmentation for other species, such as arboreal mammals and marsupials, including the tree kangaroos of tropical rainforest remnants in Australia (Laurance, 1990). This assertion is confirmed by data on populations of butterflies, dung beetles and ants in interior rainforests, rainforest edges, remnant rainforest riparian strips and arable land presented by Hill (1995). "Rainforest interior species", including the most abundant species of ants in the rainforest interior, three of the butterflies and one of the dung beetle species were found in the streamside riparian strips, but not in either the rainforest edges or arable land.

The presence of riparian margins in and around agricultural plantations allows the diversification of these habitats and maintenance of vital ecological processes, thus enabling greater persistence of species in agricultural landscapes (Tscharnkte, 2007). In 2010, a survey in an oil palm plantation in Sarawak, conducted to evaluate the variation in avian biodiversity among different habitats within the plantation, found that the presence of riparian buffer zones enhanced bird abundance and diversity in it. Although no high-conservation value species were detected in the plantation during the survey, the findings indicate that the presence of natural habitat within an oil palm plantation can help increase species diversity and aid biodiversity conservation (Wild Asia, 2011).

The importance of riparian vegetation has also been enshrined in law. For instance, Brazilian forestry legislation calls for the protection of riparian buffer zones in private land holdings (Lees and Peres, 2007). However, the importance of riparian margins, especially for protecting habitat-specific species, should not be over-estimated. While streamside vegetation and riparian margins may be helpful, research by Warkentin et al. (1995) indicates that riparian woodlands in Mexico are dominated by habitat generalists rather than pristine forest avifauna. Nevertheless, the presence of riparian margin helps in maintaining a wide range of species and species diversity in agricultural mosaics.

It is often difficult to evaluate the efficacy of tropical forest conservation programs. Hence, it is vital to develop and select appropriate metrics for assessing both the conservation value of different forest/land use types and the efficacy of conservation schemes designed to preserve them. However, more than one metric is needed to avoid biased judgement, and ideally both the conservation value (biodiversity protection and ecosystem services) and carbon sequestration offered by alternative land use types should be considered (Macdonald et al., 2011). Schemes that target the biodiversity conservation and ecosystem services potential of a land use type (e.g. Forest Stewardship Council schemes) and the carbon sequestration services provided by tropical forests (such as Reducing Emissions from Deforestation and Forest Degradation, REDD) have already been established, and need to be assessed, implemented and monitored on a case-by case basis.

\section{High conservation value forests}

High Conservation Value Forest (HCVF) approach emerged in 2001 as a supplementary standard within the Forest Stewardship Scheme. High Conservation Value Forest (HCVF) 
is a forest management standard, introduced by the Forest Stewardship Council in 2001, intended to identify and protect forest areas with critical or outstanding ecological, social and cultural values, e.g., habitats for rare threatened or endangered species, water/soil quantity and quality protection, and/or sites of cultural and/or religious significance (Levy, 2009). When a forest is designated as HCVF these attributes are identified and should be effectively managed. The concept has been transferred to the plantation sector, where progressive oil palm plantation managers use it as a means of claiming environmental responsibility. In non-forested areas, more general " $\mathrm{HCV}^{\prime}$ approaches (Jepson et al., 2011) can play important roles in guiding conservation priorities for different land use types. For instance, demarcating a forest patch as an HCVF can make a case for directing logging pressures towards other forests and plantations, with lower conservation value, where logging/agricultural expansion may be more compatible with preservation of biodiversity (Frumhoff and Losos, 1998). The demarcation of forest areas as HCVFs can also lay foundations for designing policy mechanisms or certification schemes to prevent undesirable exploitation (Gullison, 2003). Further, the HCVF approach can play a very significant role in shifting the focus from conserving a specific type of forest (such as old growth forests) to the values that make a forest important, such as its biodiversity conservation potential (Jennings et al., 2003). It can greatly promote sustainable forest management and be beneficial for forest zoning and forest benefit compensation, as well as informing nature reserve establishment (Huafeng, 2007). The concepts encompassed in $\mathrm{HCV}$ can also be applied to evaluate the conservation value of non-forest landscapes, such as human-modified habitats and mixed-rural habitats. Although primary forests have the highest conservation values, application of this scheme may allow biodiversity conservation in other land use types with high conservation values, such as secondary forests and isolated forests, by bringing them under the purview of suitable land management policies (Sodhi et al., 2004).

Arguably, in this era of rapid deforestation, designing landscapes that can reconcile biodiversity conservation and agricultural production may require different combinations of the land management approaches discussed in this chapter, with various similarities and unique features among regions.

\subsection{Reconciling biodiversity conservation with carbon storage}

One of the obvious shortcomings of the HCV concept is the neglect of carbon storage services in its defining criteria. However, it can be used in conjugation with Reducing Emissions from Deforestation and Forest Degradation (REDD) schemes to meet carbon storage objectives together with biodiversity conservation goals. Global level analysis by Strassburg et al. (2010) indicates that species richness is strongly associated with carbon stocks. However, this relation varies significantly across regions. For instance, in South East Asia plantations of rapidly growing crops, such as acacia and pines, have low biodiversity conservation potential but can enhance carbon sequestration (Corlett and Primack, 2008). Further, vital habitats for vulnerable and endemic species may not overlap with areas of high carbon storage. Hence, measures that promote the persistence of conservation-dependent species may not necessarily assist carbon 
sequestration. Hence, spatial planning should ideally aim to maximize biodiversity and enhance carbon storage simultaneously (ProForest, 2011).

"Designer landscape" is a theoretical concept with important practical implications. In South East Asia oil palm monoculture-forest mosaics comprise a substantial part of many landscapes (Koh et al., 2009), in which remnants of primary, old growth forests occur as fragmented, isolated patches of various sizes in a matrix of oil palm plantations (Bennett, 2003). In this situation, more heterogeneous, designer landscapes could be created by incorporating features such as agroforestry zones between high conservation value forests and oil palm monoculture plantations. Further, isolated and fragmented habitat patches could be connected across such landscapes by retaining or creating wildlife corridors (Koh et al., 2009).

Struebig et al. (2010) argued that the designer landscape approach is highly context-dependent and constrained by socio-political and biological realities. Nevertheless, in principle there is some room for a designer approach, to develop landscapes where oil palm plantations co-exist with forests, in partnership with local communities, which could yield significant conservation benefits (Phalan, 2009). Ghazoul et al. (2010) recognise risks (wildlife conflicts, hunting and encroachment) inherent in the approach advocated by Struebig et al. (2010), but argue that a strict land-sparing and/or HCV combination would be subject to similar risks. Given that biodiversity and ecosystem services are increasingly expected to persist in a human-modified landscape, the practical realities (and feasibility) of the 'designer landscape' approach should be carefully considered. Many configurations of landscape level strategies could allow the creation of designer landscapes that meet desired goals. However, very few landscape level studies have been carried out that could form the theoretical basis for informing these landscape level strategies and the subsequent creation of designer landscapes. In addition to the on-going Stability of Altered Forest Ecosystem (SAFE) project in Danum, examining the effects of fragmentation, Laurance et al. (2011) have presented results of a 32-year study on Amazonian forest fragments. The results indicate that species in forest fragments are vulnerable to edge effects and that isolation effects decline with the recovery of secondary forests. However, there have been very few landscape level studies that could provide a sound theoretical basis for informing landscape level strategies and subsequent creation of designer landscapes. Thus, further examination of both patch level processes and wider landscape contextual issues is required to facilitate the creation of designer landscapes that meet multiple (often conflicting goals) in given areas.'

\section{Conclusions}

Agricultural expansion, driven by rapid increases in the human population, is a major cause of deforestation, biodiversity losses and environmental degradation globally, especially in the tropics. Accompanying searches for land to support the increases in agricultural production, and increase revenues, have caused significant losses, modifications and fragmentation of habitats, which are posing substantial threats to the world's biodiversity, forests and ecosystems. There have been considerable efforts to protect biodiversity in reserves and parks, but 
many of the refuges are small, fragmented, isolated, or poorly protected. In addition, most Protected Areas are embedded in agricultural landscapes, and existing buffer zones are inadequate for alleviating effects of fragmentation, contamination by agrochemicals, hunting, and unsustainable or illegal logging. In recent decades, the expansion of oil palm monocultures has been one of the most significant drivers of deforestation and habitat loss in various tropical regions, including South East Asia, which hosts four biodiversity hotspots and is particularly vulnerable to these processes. The replacement of natural forest cover with oil palm monoculture plantations has detrimental effects on the biodiversity in the region, since they support substantially less biodiversity than the primary forests or even the disturbed and logged forests they replace. This is largely due to the absence of major structurally complex components of forest vegetation (including forest trees, lianas and epiphytic orchids) and associated fauna, including numerous threatened, iconic species.

In addition to adversely affecting biodiversity, oil palm expansion also increases carbon emissions in South East Asia, reportedly resulting in a net release of approximately $650 \mathrm{Mg}$ $\mathrm{CO}_{2}$ equivalents per hectare or more, resulting in a "biofuel carbon debt" by releasing 17 to 420 times more $\mathrm{CO}_{2}$ than the annual GHG reductions that oil palm-derived biofuels would provide by displacing fossil fuels. Estimates indicate that it could take 75-93 years for carbon emissions saved from the use of biofuels to compensate for the carbon released by forest conversion. Furthermore, less than pristine human-modified landscapes also have considerable conservation and carbon storage potential. For instance, more than $90 \%$ of the species recorded in primary forests have been found in logged forests, and during recovery logged forests may accumulate carbon five times more rapidly than natural forest, providing substantial carbon storage. In addition, marginal and/or degraded habitats often found within or nearby palm oil concessions can retain high conservation values. Thus, in order to create palm oil monocultures that do not damage the local biodiversity and carbon stocks, it is vital to include human modified/degraded landscapes in any conservation program for a given area.

The fate of biodiversity within patches of lowland forests is inextricably linked to the broader landscape context, including how the surrounding agricultural matrix is designed and managed. Species are more likely to persist in protected areas that incorporate local environmental heterogeneity, because it provides a range of conditions that allows them to adjust their local distribution in response to environmental changes. Other land use types can also counter the adverse effects of oil palm monocultures on biodiversity. Notably, other plantation systems such as cocoa agroforests and mixed fruit orchards may provide valuable habitats, because complex multi-species plantations (especially those that encompass remnants of native vegetation) bear significant resemblance to primary vegetation. This has important implications both for conservation strategies and the design of oil palm plantations, which may entail the use of modified landscapes and new planning strategies to reduce impacts on local biodiversity.

Two contrasting management approaches have been recommended for boosting agricultural production while maintaining biodiversity: land sparing, which increases farm yields while reducing pressure to convert land for agriculture (at the potential cost of reducing wildlife populations on farmland) and land sharing/wildlife friendly farming, in which on-farm practices that are benign to wildlife are applied. In land sparing, homogeneous areas of 
farmland are managed to maximize yields, while separate reserves target biodiversity conservation. Inputs of fertilizers and pesticides are generally high, crop diversity usually low, and individual fields tend to be large. Land sparing is a weak conservation strategy, and can be applied under a limited set of circumstances, but it can have positive outcomes for nature conservation. Notably, from a conservation perspective the protection of primary contiguous forest appears to be more beneficial than investing in the retention of fragments. However, despite its proposed benefits, the land sparing approach has been heavily critiqued, since intensive agricultural systems may fail to spare land for nature and the high use of agricultural inputs may adversely impact areas downstream from the agricultural farms.

In wildlife-friendly farming, as opposed to land sparing, conservation and production are integrated within more heterogeneous landscapes, recognizing: that biodiversity is retained in agricultural landscapes; that we need to understand and effectively manage the degree of biodiversity retention; and that many species can be conserved by modifying existing agricultural landscapes through the principles of eco-agriculture. In wildlife-friendly farming, agricultural yields tend to be lower. Therefore, larger land areas are typically required to produce the same agricultural yield. This leaves less land for permanent preservation, but more biodiversity may be retained on the "wildlife-friendly" agricultural land itself. Hence, wildlife friendly land planning strategies should be considered important components of integrated landscape conservation strategies.

Both land sparing and land sharing have pros and cons. Further, the optimal strategy for maintaining production and biodiversity differs between landscapes (Hodgson et al., 2010). The choice of strategy could be informed by yield-density relations, i.e. relationships between population densities of particular species and agricultural yields. Land sparing may be most appropriate for species whose populations decline rapidly when their natural intact habitat is converted to low intensity agricultural landscapes, while wildlife friendly farming may be more appropriate for species whose densities are maintained when the intact natural habitat is converted to low yield agricultural landscapes (Mattison and Norris, 2005). However, a strategy combining the two approaches may be optimal in many cases, incorporating (for instance) the creation of agroforestry zones between high conservation value areas and intensive agricultural plantations to create more heterogeneous landscapes that can benefit both biodiversity and rural communities. Nevertheless, before selecting any of the abovementioned approaches numerous other landscape level factors should be considered. These include the permeability of sensitive species through habitats and their physiological traits. No heavily human-modified landscapes can be regarded as a full substitute for primary forest habitats, but they may allow the preservation of biodiversity if appropriately fragmented or designed. However, in order to design an appropriate landscape, characteristics of the surrounding matrix and the ability of sensitive species to adapt to it have to be addressed, and both the value and characteristics of potentially important elements need to be considered. Such elements may include rainforest fragments, high conservation value forests, wildlife corridors and riparian margins.

Several strategies have been recommended for establishing landscape patterns that are likely to maintain many species and ecological processes in production landscapes. The most 
important is the maintenance of large patches of native vegetation, which are very important for maintaining vital ecological processes and (hence) the persistence of biodiversity. In addition, maintenance of structural complexity, an appropriate (preferably native vegetation) "matrix" and suitable levels of connectivity between elements is vital. A matrix with a similar vegetation structure to that of native vegetation supplies a variety of ecosystem benefits, support for ecological processes, habitats for species outside patches of native vegetation or protected areas, shelter, breeding sites, additional food resources and the ability to recover from disturbance. Oil palm plantations, in particular, can be made wildlife friendly by the preservation of forest fragments, riparian strips, etc., and/or by providing habitat complexity within the plantations in the form of epiphytes and understory plants. "Extinction debt" must also be considered, i.e. populations that have survived extensive habitat loss may still face extinction owing to a time lag between initial habitat loss and eventual population decline.

Finally, it is essential to integrate biodiversity conservation with robust carbon storage strategies. Global level analysis indicates that species richness is strongly associated with carbon stocks, but the strength of the relationship varies significantly across regions. For instance, in South East Asia plantations of fast-growing crops, such as acacia and pines, have low biodiversity conservation potential but may have high carbon sequestration value. Further, vital habitats of vulnerable and endemic species may not overlap with areas of high carbon storage. Thus, spatial planning that maximizes biodiversity co-benefits along with carbon storage is required.

It has been argued that the designer landscape approach is highly context-dependent and constrained by socio-political and biological realities. Further, many configurations of landscape level strategies could allow the creation of designer landscapes that meet desired goals. Thus, further research on (inter alia) patch-level processes and wider contextual issues is required to develop robust strategies for creating designer landscapes that meet often conflicting conservation, agricultural production and carbon sequestration goals.

\section{Author details}

Minerva Singh and Shonil Bhagwat

University of Oxford, UK

\section{References}

[1] Anderson, B. J, Armsworth, P. R, Eigenbrod, F, Thomas, C. D, Gillings, S, Heinemeyer, A, Roy, D. B, \& Gaston, K. J. (2009). Spatial covariance between biodiversity and other ecosystem service priorities' Journal of Applied Ecology, 46 (4), 888-896. 
[2] Angelsen, A. (1999). Agricultural expansion and deforestation: modelling the impact of population, market forces and property rights'. Journal of Development Economics, , 58(1), 185-218.

[3] Aratrakorn, S, Thunhikorn, S, \& Donald, P. F. (2006). Changes in bird communities following conversion of lowland forest to oil palm and rubber plantations in southern Thailand'. Bird Conservation International, 16 (1), 71-82.

[4] Arroyo-rodriguez, V, Pineda, E, Escobar, F, \& Bénitez-malvido, J. (2009). Value of small patches in the conservation of plant-species diversity in highly fragmented rainforest'. Conservation Biology, , 23(3), 729-739.

[5] Balmford, A, Green, R. E, \& Scharlemann, P. W. (2005). Sparing land for nature: exploring the potential impact of changes in agricultural yield on the area needed for crop production'. Global Change Biology, , 11(10), 1594-1605.

[6] Barlow, J, Gardner, T. A, Araujo, I. S, et al. (2007). Quantifying the biodiversity value of tropical primary, secondary and plantation forests'. Proceedings of the National Academy of Sciences, , 104(47), 18555-18560.

[7] Benedick, S, Hill, J. K, Mustaffa, N, Chey, V. K, Maryati, M, Searle, J. B, Schilthuizen, M, \& Hamer, K. C. (2006). Impacts of rain forest fragmentation on butterflies in northern Borneo: species richness, turnover and the value of small fragments'. Journal of Applied Ecology, , 43(5), 967-977.

[8] Bengtsson, J, Angelstam, P, Elmqvist, T, Emanuelsson, U, Folke, C, Ihse, M, Moberg, F, \& Nystrom, M. (2003). Reserves, resilience and dynamic landscapes'. Ambio, , 32(6), 389-396.

[9] Bennett, A. F. (2003). Linkages in the landscape: the role of corridors and connectivity in wildlife conservation, 2nd edn. IUCN, Gland, Switzerland and Cambridge, UK.

[10] Berry, N, Phillips, O, Lewis, S, Hill, J, Edwards, D, Tawatao, N, Ahmad, N, Magintan, D, Khen, C, Maryati, M, Ong, R, \& Hamer, K. (2010). The high value of logged tropical forests: lessons from northern Borneo'. Biodiversity and Conservation, 19 (4), 985-997.

[11] Beukema, H, Danielsen, F, Vincent, G, Hardiwinoto, S, \& Van Andel, J. (2007). Plant and bird diversity in rubber agroforests in the lowlands of Sumatra'. Agroforestry Systems , 70(3), 217-242.

[12] Bhagwat, S. A, Cushalappa, C. G, Williams, P. H, \& Brown, N. D. (2005). A landscape approach to biodiversity conservation of sacred groves in the Western Ghats of India'. Conservation Biology, , 19(6), 1853-1862.

[13] Bhagwat, S. A, Willis, K. J, Birks, H. J. B, \& Whittaker, R. J. (2008). Agroforestry: a refuge for tropical biodiversity?' Trends in Ecology and Evolution, , 23(5), 261-267. 
[14] Bhagwat, S. A, Cole, L. E. S, \& Willis, K. J. (2010). Biodiversity conservation, rural livelihoods and sustainability of oil palm landscapes: problems and prospects.

[15] Blann, K. (2006). Habitat in Agricultural Landscapes: How Much is Enough? West Linn: Defenders of Wildlife.

[16] Broadbent, E. N, Asner, G. P, Keller, M, Knapp, D. E, Oliveira, P. C. J, \& Silva, J. N. (2008). Forest fragmentation from deforestation and selective logging in the Brazilian Amazon'. Biological Conservation, , 141(7), 1745-1757.

[17] Brook, B. W, Sodhi, N. S, \& Ng, P. K. L. (2003). Catastrophic extinctions follow deforestation in Singapore', Nature, $424,420-423$.

[18] Brühl, C. A, Eltz, T, \& Linsemair, K. E. (2003). Size does matter- effects of tropical rainforest fragmentation on leaf litter and ant community in Sabah, Malaysia'. Biodiversity and Conservation, , 12(7), 1371-1389.

[19] Butler, R. mongabay.com (October 04, (2007). Biodiesel demand could destroy world's forests. http://news.mongabay.com/2007/biodiesel.htmlLast accessed: August 14,2012

[20] Caro, T, Gardner, T. A, Stoner, C, Fitzherbert, E, \& Davenport, T. R. B. (2009). Assessing the effectiveness of protected areas: paradoxes call for pluralism in evaluating conservation performance'. Diversity and Distributions, , 15(1), 178-182.

[21] Castellon, T. D, \& Sieving, K. E. (2006). An Experimental Test of Matrix Permeability and Corridor Use by an Endemic Understory Bird'. Conservation Biology, , 20(1), 135-145.

[22] Chazdon, R. L. (2003). Tropical forest recovery: legacies of human impact and natural disturbances'. Perspectives in Plant Ecology, Evolution and Systematics, , 6(1), 51-71.

[23] Chazdon, R. L, Harvey, C. A, Komar, O, Griffith, D. M, Ferguson, B. G, Martínez-ramos, M, Morales, H, Nigh, R, Soto-pinto, L, Van Breugel, M, \& Philpott, S. M. (2009). Beyond reserves: a research agenda for conserving biodiversity in human-modified tropical landscapes'. Biotropica, 41 (2), 142-153.

[24] Chey, V. K. (2006). Impacts of forest conversion on biodiversity as indicated by moths'. Malayan Nature Journal , 57(4), 383-418.

[25] Chung, A. Y. C, Eggleton, P, Speight, M. R, Hammond, P. M, \& Chey, V. K. (2000). The diversity of beetle assemblages in different habitat types in Sabah, Malaysia'. Bulletin of Entomological Research, , 90(6), 475-496.

[26] Clay, J. W. (2004). World Agriculture and the Environment. Washington, DC: Island Press.

[27] Corlett, R. T, \& Primack, R. B. (2008). Tropical Rainforest Conservation: A Global perspective'. In: Carlson, W. and Schnitzer, S. (eds). Tropical Forest Community Ecology. Oxford: Wiley-Blackwell. , 442-457. 
[28] Corley, R. H. V, \& Tinker, P. B. (2003). The Oil Palm. $4^{\text {th }}$ edition. Oxford: Blackwell Science Ltd.

[29] Corley, R. H. V. (2009). How much palm oil do we need?' Environmental Science and Policy 12 (2), 134-139.

[30] Cowlishaw, G. (1999). Predicting the Pattern of Decline of African Primate Diversity: an Extinction Debt from Historical Deforestation'. Conservation Biology, 13 (5), 1183-1193.

[31] Daily, G. C, \& Ehrlich, P. R. (1995). Preservation of biodiversity in small rainforest patches: rapid evaluations using butterfly trapping'. Biodiversity and Conservation, 4 (1), 35-55.

[32] Danielsen, F, \& Heegaard, M. (1995). Impact of logging and plantation development on species diversity: a case study from Sumatra'. In: Sandbukt, O. (ed.) Management of tropical forests: towards an integrated perspective. Oslo: Centre for Development and the Environment, University of Oslo. , 73-92.

[33] Danielsen, F, Beukema, H, Burgess, N. D, Parish, F, Brühl, C. A, Donald, P. F, Murdiyarso, D, Phalan, B, Reijnders, L, Struebig, L, \& Fitzherbert, E. B. (2009). Biofuel Plantations on Forested Lands: Double Jeopardy for Biodiversity and Climate'. Conservation Biology, , 23(2), 348-358.

[34] Defries, R, Asner, G. P, Achard, F, Justice, C, Laporte, N, Price, K, Small, C, \& Townshend, J. (2005). Monitoring tropical deforestation for emerging carbon markets'. In: Moutinho, P. and Schwartzman, S. (eds.) Tropical Deforestation and Climate Change. Washington, DC: IPAM. , 1-27.

[35] Diamond, J. M. (1975). The island dilemma: lessons of modern biogeographic studies for the design of natural reserves'. Biological Conservation, 7 (2), 129-146.

[36] Dunn, R. R. (2004). Recovery of faunal communities during tropical forest regeneration'. Conservation Biology, , 18(2), 302-309.

[37] Edwards, D. P, Fisher, B, \& Boyd, E. (2010). Protecting degraded rainforests: enhancement of forest carbon stocks under REDD+'. Conservation Letters, , 3(5), 313-316.

[38] Edwards, D. P, Larsen, T. H, Docherty, T. D. S, Ansell, F. A, Hsu, W. W, Dehré, M. A, Hamer, K. C, \& Wilcove, D. S. (2011). Degraded lands worth protecting: the biological importance of Southeast Asia's repeatedly logged forests'. Proceedings of the Royal Society B, 278 (1702), 82-90.

[39] Elevitch, C. R. ed.). ((2004). The Overstory Book: Cultivating Connections with Trees. $2^{\text {nd }}$ Edition. Holualoa: Permanent Agriculture Resources.

[40] Elmqvist, T, Folke, C, Nyström, M, Peterson, G, Bengtsson, J, \& Walker, B. And Norberg, J. ((2003). Response diversity, ecosystem change, and resilience'. Frontiers in Ecology and the Environment, , 1(9), 488-494. 
[41] Estrada, A, \& Coates-estrada, R. (2002). Dung beetles in continuous forest, forest fragments and in an agricultural mosaic habitat island at Los Tuxtlas, Mexico'. Biodiversity and Conservation, , 11(11), 1903-1918.

[42] Ewers, R. M, Scharlemann, J. P. W, Balmford, A, \& Green, R. E. (2009). Do increases in agricultural yield spare land for nature?' Global Change Biology, 15 (7), 1516-1526.

[43] Fahrig, L. (2001). How much habitat is enough?' Biological Conservation, 100 (1), 65-74.

[44] FAO (2009). FAO statistics: Production and crops. The Food and Agriculture Organization of the United Nations. Available at: http://faostat.fao.org/site/567/ default.aspx\#ancor.Accessed 12 August 2012)

[45] Fargione, J, Hill, J, Polasky, S, \& Hawthorne, P. (2008). Land clearing and the biofuel carbon debt'. Science, , 319(5867), 1235-1238.

[46] Fayle, T. M, Turner, E. C, Snaddon, J. L, Chey, V. K, Chung, A. Y. C, Eggleton, P, \& Foster, W. A. (2010). Oil palm expansion into rain forest greatly reduces ant biodiversity in canopy, epiphytes and leaf- litter'. Basic and Applied Ecology, 11(4), 337-345.

[47] Finegan, B, \& Nasi, R. (2004). The biodiversity and conservation potential of shifting cultivation landscapes'. In: Schroth, G., da Fonseca, G.A.B., Harvey, C.A., Gascon, C., Vasconcelos, H. L. and Izac, A.M.N. (eds.). Agroforestry and biodiversity conservation in tropical landscapes. Washington, DC: Island Press. , 153-197.

[48] Fischer, J, Lindenmayer, D. B, \& Manning, A. D. (2006). Biodiversity, ecosystem function, and resilience: ten guiding principles for commodity production landscapes' Frontiers in Ecology and the Environment, , 4(2), 80-86.

[49] Fischer, J, Brost, B, Daily, G. C, Ehlrich, P. R, Goldman, R, Goldstein, J, Lindenmayer, D. B, Manning, A. D, Mooney, H. A, Pejchar, L, Ranganathan, J, \& Tallis, H. (2008). Should agricultural policies encourage land sparing or wildlife- friendly farming'. Frontiers in Ecology and the Environment, , 6(7), 380-385.

[50] Fitzherbert, E. B, Struebig, M. J, Morel, A, Danielsen, F, Brühl, C. A, Donald, P. F, \& Phalan, B. (2008). How will oil palm expansion affect biodiversity?' Trends in Ecology and Evolution, , 23(10), 538-545.

[51] Forman, R. T. T. (1995). Land Mosaics: The ecology of landscapes and regions. New York, NY: Cambridge University Press.

[52] Friends of the Earth ((2009). The Oil for Ape Scandal. Available at: http:// www.foe.co.uk/resource/reports/oil_for_ape_summary.pdfAccessed 12 August 2012)

[53] Frumhoff, P. C, \& Losos, E. C. (1998). Setting priorities for conserving biological diversity in tropical timber production forests. Washington, DC: Center for Tropical Forest Science, Smithsonian Institute. 
[54] Fukuda, D, Tisen, O. B, Momose, K, \& Sakai, S. (2009). Bat diversity in the vegetation mosaic around a lowland Dipterocarp forest of Borneo'. Raffles Bulletin of Zoology , 57(1), 213-221.

[55] Gaston, K. J, Blackburn, T. M, \& Goldewijk, K. K. (2003). Habitat conversion and global avian biodiversity loss'. Proceedings of the Royal Society B, 270 (1521), 1293-1300.

[56] Gaveau, D. L. A, Epting, J, Lyne, O, Linkie, M, Kumara, I, Kanninen, M, \& Leaderwilliams, N. (2009). Evaluating whether protected areas reduce tropical deforestation in Sumatra'. Journal of Biogeography, , 36(11), 2165-2175.

[57] Germer, J, \& Sauerborn, J. (2008). Estimation of the impact of oil palm plantation establishment on greenhouse gas balance'. Environment, Development and Sustainability, 10 (6), 697-716.

[58] Ghazoul, J, Koh, L. P, \& Levang, P. (2010). Checking the reality check'. Trends in Ecology and Evolution, 25(1), 8-9.

[59] Gilbert, F, Gonzalez, A, \& Evans-freke, I. (1998). Corridors maintain species richness in the fragmented landscapes of a microecosystem' Proceedings of the Royal Society B, 256 (1396), 577-582.

[60] Gillies, C. S. and St. Clair, C.C. ((2008). Riparian corridors enhance movement of a forest specialist bird in fragmented tropical forest'. Proceedings of the National Academy of Sciences, 105 (50), 19774-19779.

[61] Gillson, L, \& Willis, K. J. (2004). As Earth's testimonies tell': wilderness conservation in a changing world'. Ecology Letters, , 7(10), 990-998.

[62] Goklany, I. M. (1998). Saving habitat and conserving biodiversity on a crowded planet'. BioScience, , 48, 941-953.

[63] Green, R. E, Cornell, S. J, Scharlemann, J. P. W, \& Balmford, A. (2005). Farming and the fate of wild nature'. Science, 307(5709), 550-555.

[64] Gullison, R. E. (2003). Does forest certification conserve biodiversity?' Oryx, 37 (2), 153-165.

[65] Hamer, K. C, Hill, J. K, Benedick, S, Mustaffa, N, Maryati, M, \& Chey, V. K. (2003). Ecology of butterflies in natural and selectively logged forests of northern Borneo: the importance of habitat heterogeneity'. Journal of Applied Ecology, , 40(1), 150-162.

[66] Hartley, M. J. (2002). Rationale and methods for conserving biodiversity in plantation forests'. Forest Ecology and Management, 155(1-3): 81-95.

[67] Harvey, C. A, \& Medina, A. Sánchez Merlo, D., Vílchez, S., Hernández, B., Saenz, J.C., Maes, J.M., Casanovas, F. and Sinclair, F.L. ((2006a). Patterns of animal diversity associated with different forms of tree cover retained in agricultural landscapes'. Ecological Applications, , 16(5), 1986-1999. 
[68] Harvey, C. A, González, J, \& Somarriba, E. (2006b). Dung beetle and mammal diversity in forests, indigenous agroforestry systems and plantain monocultures in Talamanca, Costa Rica'. Biodiversity and Conservation , 15(2), 555-585.

[69] Harvey, C. A. (2007). Designing agricultural landscapes for biodiversity conservation'. In Scherr, S.J. and McNeely, J.A. (eds.). Farming with nature: The science and practice of ecoagriculture. Washington, DC: Island Press. , 146-165.

[70] Harvey, C. A, \& Gonalez-villalobos, J. A. (2007). Agroforestry systems conserve species-rich but modified assemblages of tropical birds and bats'. Biodiversity and Conservation , 16(8), 2257-2292.

[71] Harvey, C. A, Komar, O, Chazdon, R, Ferguson, B. G, Finegan, B, Griffith, D. M, Martínez-ramos, M, Morales, H, Nigh, R, Soto-pinto, L, Van Breugel, M, \& Wishnie, M. (2008). Integrating agricultural landscapes with biodiversity conservation in the Mesoamerican hotspot'. Conservation and Policy, 22 (1), 8-15.

[72] Hill, J. K, Hamer, K. C, Lace, L. A, \& Banham, W. M. T. (1995). Effects of selective logging on tropical forest butterflies on Buru, Indonesia'. Journal of Applied Ecology, 32(4), 754-760.

[73] Hilty, J. A, Lidicker, W. Z, \& Merenlender, A. M. (2006). Corridor ecology: The science and practice of linking landscapes for biodiversity conservation. Washington, DC: Island Press.

[74] Hodgson, J. A, Kunin, W. E, Thomas, C. D, Benton, T. G, \& Gabriel, D. (2010). Comparing organic farming and land sparing: optimizing yield and butterfly populations at a landscape scale'. Ecology Letters 13 (11), 1358-1367.

[75] Hole, D. G, Perkins, A. J, Wilson, J. D, Alexander, I. H, Grice, F, \& Evans, A. D. (2005). Does organic farming benefit biodiversity?' Biological Conservation, , 122(1), 113-130.

[76] Holzschuh, A, Steffan-dewenter, I, \& Tscharntke, T. (2008). Agricultural landscapes with organic crops support higher pollinator diversity'. Oikos, , 117(3), 354-361.

[77] Hooijer, A, Silvius, M, Wösten, H, \& Page, S. (2006). PEAT- $\mathrm{CO}_{2}$, Assessment of $\mathrm{CO}_{2}$ emissions from drained peatlands in SE Asia'. Delft Hydraulics report Q3943 (2006)

[78] Horskins, E. (2005). The Effectiveness of Wildlife Corridors in Facilitating Connectivity: Assessment of a Model System from the Australian Wet Tropics. PhD thesis, Queensland University of Technology.

[79] Huafeng, D. K. D. (2007). High Conservation Value Forests Theory,Practice and Future Tendency'. World Forestry Research, , 2007 - 05.

[80] Jackson, L, Van Noordwijk, M, Bengtsson, J, Foster, W, Lipper, L, Pulleman, M, Said, M, Snaddon, J, \& Vodouhe, R. (2010). Biodiversity and agricultural sustainagility: 
from assessment to adaptive management'. Current Opinion in Environmental Sustainability, 2(1-2): 80-87.

[81] Jennings, S, Nussbaum, R, Judd, N, \& Evans, T. (2003). The High Conservation Value Forest Toolkit'. ProForest. Available at: http://lvoh.aprojekt.sk/upload/File/medzinarodny\%20koncept/hcvftoolkitglobal.pdfAccessed 13 August 2012)

[82] Jepson, P, Barua, M, \& Buckingham, K. (2011). What is a conservation actor?' Conservation and Society, 9 (3), 229-235.

[83] Kaimowitz, D, \& Angelsen, A. (1998). Economic Models of Tropical Deforestation: A Review. Bogor, Indonesia: Centre for International Forestry Research.

[84] Koh, L. P, \& Wilcove, D. S. (2007). Cashing in palm oil for conservation'. Nature, , 448, 993-994.

[85] Koh, L. P. (2008). Can oil palm plantations be made more hospitable for forest butterflies and birds?' Journal of Applied Ecology, , 45(4), 1002-1009.

[86] Koh, L. P, Levang, P, \& Ghazoul, J. (2009). Designer landscapes for sustainable biofuels'. Trends in Ecology and Evolution, 24 (8), 431-438.

[87] Koh, L. P, Miettinen, J, Liew, S. C, \& Ghazoul, J. (2011). Remotely sensed evidence of tropical peatland conversion to oil palm', Proceedings of the National Academy of Sciences, 108 (12), 5127-5132.

[88] Komar, O. (2006). Ecology and conservation of birds in coffee plantations: a critical review'. Bird Conservation International, , 16(1), 1-23.

[89] Laurance, W. F. (1990). Edge effects in tropical forest fragments: Application of a model for the design of nature reserves'. Biological Conservation, 57 (2), 205-219.

[90] Laurance, S. G, \& Laurance, W. F. (1999). Tropical wildlife corridors: use of linear rainforest remnants by arboreal mammals'. Biological Conservation, 91(2-3): 231-239.

[91] Laurance, W. F, \& Peres, C. A. eds.). ((2006). Emerging Threats to Tropical Forests Chicago: University of Chicago Press.

[92] Laurance, W. F, Camargo, J. L. C, Luizão, R. C. C, et al. (2011). The fate of Amazonian forest fragments: a 32 year investigation', Biological Conservation, 144 (1), 56-67.

[93] Lees, A. C, \& Peres, C. A. (2007). Conservation Value of Remnant Riparian Forest Corridors of Varying Quality for Amazonian Birds and Mammals'. Conservation Biology, , 22(2), 439-449.

[94] Leplay, S, Busch, J, Delacote, P, \& Thoyer, S. (2010). Local and national REDD income under alternative PES designs: theory and illustration from Sumatra', International Conference: Environment and Natural Resources Management in Developing and Transition Economies CERDI November. Clermont Ferrand., 18-19. 
[95] Levy, M. (2009). A Review of High Conservation Value Forest (HCVF) Assessments in intensively managed plantations'. OCTF, http://www.eci.ox.ac.uk/octf/events/ junlevy.pdf

[96] Lindenmayer, D. B, \& Hobbs, R. J. (2004). Fauna conservation in Australian plantation forests- A review', Biological Conservation , 119(2), 151-168.

[97] Lovejoy, T. E. Bierregaard Jr., R.O., Rylands, A.B., Malcom, J.R., Quintela, C.E., Harper, L.H., Brown Jr., K.S., Powell, A.H., Powell, G.V.H., Schubart, H.O.R. and Hays, M.B. ((1986). Edge and other effects of isolation on Amazon forest fragments'. In: Soulé, M.E. (ed.). Conservation Biology: the Science of Scarcity and Diversity. Sunderland, MA: Sinauer Associates Inc. , 257-285.

[98] Lovejoy, T. E, \& Hannah, L. eds.). ((2005). Climate Change and Biodiversity. Michigan: Yale University Press.

[99] Macdonald, E. A, Collins, M, Johnson, P. J, Clayton, L. M, Malhi, Y, Fisher, J. B, Milner-gulland, E. J, \& Macdonald, D. W. (2011). Wildlife conservation and reduced emissions from deforestation in a case study of Nantu National Park, Sulawesi 1. The effectiveness of forest protection- many measures, one goal'. Environmental Science and Policy , 14(6), 697-708.

[100] Maddox, T, Priatna, D, Gemita, E, \& Salmpessy, A. (2007). The conservation of tigers and other wildlife in oil palm plantations, Jambi Province, Sumatra, Indonesia (October 2007). London: Zoological Society of London.

[101] Matson, P. A, \& Vitousek, P. M. (2006). Agricultural intensification: will land spared from farming be land spared for nature?' Conservation Biology, , 20(3), 709-710.

[102] Mattison, E. H. A, \& Norris, K. (2005). Bridging the gaps between agricultural policy, land-use and biodiversity'. Trends in Ecology and Evolution, , 20(11), 610-616.

[103] Moguel, P, \& Toledo, V. M. (1999). Biodiversity conservation in traditional coffee systems of Mexico'. Conservation Biology, , 13(1), 11-21.

[104] Moll, J, Crosthwaite, J, Dorrough, J, Shea, D, Shea, R, Moxham, C, \& Straker, A. (2007). Farm businesses can profitably manage biodiversity'. A paper to the Conference: Biodiversity Balancing Conservation and Production-Case Studies from the Real World, Launceston, June 2007., 26-28.

[105] Mongabay (2012). http://news.mongabay.com/2012/ucs_vegetable_oil_deforestation.html>Last accessed Aug 16, 2012

[106] Myers, N. (1989). A major extinction spasm: predictable and inevitable?' In: Western, D. and Pearl, M.C. (eds.). Conservation for the twenty-first century, New York, NY. Oxford University Press. , 42-49.

[107] Newmark, W. D. (1993). The role and design of wildlife corridors with examples from Tanzania'. Ambio , 22(8), 500-504. 
[108] Newmark, W. D. (1996). Insularization of Tanzanian parks and the local extinction of large mammals'. Conservation Biology, 10 (6), 1549-1556.

[109] Norris, K. (2008). Agriculture and biodiversity conservation: opportunity knocks'. Conservation Letters, , 1(1), 2-11.

[110] Peh, K. S-H, Sodhi, N. S, De Jong, J, Sekercioglu, C. H, Yap, C. A-M, \& Lim, S. L-H. (2006). Conservation value of degraded habitats for forest birds in southern Peninsular Malaysia'. Diversity and Distributions , 12(5), 572-581.

[111] Perfecto, I, Vandermeer, J, Mas, A, \& Soto-pinto, L. (2005). Biodiversity, yield, and shade coffee certification'. Ecological Economics, 54 (4), 435-446.

[112] Perfecto, I, \& Vandermeer, J. (2008). Biodiversity conservation in tropical agroecosystems: A new paradigm'. Annals of the New York Academy of Science, (The Year in Ecology and Conservation Biology 2008) 1134: 173-200.

[113] Perfecto, I, Vandermeer, J, \& Wright, A. (2009). Nature's matrix: Linking agriculture, Conservation and food sovereignty. London: Earthscan Press.

[114] Perfecto, I, \& Vandermeer, J. (2010). The agricultural matrix as an alternative to the land-sparing/agricultural intensification model: facing the food and biodiversity crises'. Proceedings of the National Academy of Sciences, 107 (13), 5786-5791.

[115] Persey, S, \& Anhar, S. (2010). Biodiversity Information for Oil Palm'. $2^{\text {nd }}$ International Conference on Oil Palm and Environment 2010: Measurement and mitigation of environmental impact of palm oil production. Bali, INDONESIA February. Proceeding ICOPE 2010., 23-25.

[116] Phalan, B. (2009). Does farming have to cost the earth?' Department of Zoology, University of Cambridge. Available at: http://www.srcf.ucam.org/awtbi/documents/ Doesfarminghavetocosttheearth.pdfAccessed 14 August 2012)

[117] Phillipps, Q, \& Phillipps, K. (2010). Phillipps' Field Guide to the Birds of Borneo: Sabah, Sarawak, Brunei and Kalimantan. Midpoint Trade Books.

[118] Pimm, S. L, \& Raven, P. (2000). Biodiversity: Extinction by numbers'. Nature, , 403, 843-845.

[119] Pineda, E, Moreno, C, Escobar, F, \& Halffter, G. (2005). Frog, bat, and dung beetle diversity in the cloud forest and coffee agroecosystems of Veracruz, Mexico'. Conservation Biology, , 19(2), 400-410.

[120] Polasky, S, Nelson, E, Lonsdorf, E, Fackler, P, \& Starfioeld, A. (2005). Conserving species in a working landscape: land use with biological objectives'. Ecological Applications, , 15(4), 1387-1401.

[121] Puechmaille, S. J, Soisook, P, Yokobul, M, \& Piyapan, P. Ar Gouilh, M., Khin, M.M., Khin, K.K., Mackie, I., Bumrungsri, S., Dejtaradol, A., Tin, N., Si Si, H.B., Satasook, C., Bates, P. and Teeling, E. ((2009). Population size, distribution, threats and conser- 
vation status of two endangered bat species Craseonycteris thonglongyai and Hipposideros turpis'. Endangered Species Research, 8(1-2): 15-23.

[122] Rice, R. A, \& Greenberg, R. (2000). Cacao cultivation and the conservation of biological diversity'. Ambio , 29(3), 167-173.

[123] Ricketts, T. H. (2004). Tropical forest fragments enhance pollinator activity in nearby coffee crops'. Conservation Biology, 18 (5), 1262-1271.

[124] Round, P. D, Gale, G. A, \& Brockelman, W. Y. (2006). A comparison of bird communities in mixed fruit orchards and natural forest at Khao Luang, southern Thailand'. Biodiversity and Conservation, 15 (9), 2873-2891.

[125] Scherr, S. J. and McNeely, J.A (eds). ((2007). Farming with Nature: the Science and Practice of Ecoagriculture. Washington, DC: Island Press.

[126] Schroth, G. (2003). Decomposition and nutrient supply from biomass'. In: Schroth G, Sinclair FL (eds.) Trees, crops and soil fertility: concepts and research methods. Wallingford: CAB International. , 131-150.

[127] Schroth, G. da Fonseca, G.A.B., Harvey, C.A., Gascon, C., Vasconcelos, H. L. and Izac, A.M.N. (eds.) ((2004). Agroforestry and biodiversity conservation in tropical landscapes. Washington, DC: Island Press.

[128] Sheldon, F. H, Styring, A, \& Hosner, P. A. (2010). Bird species richness in a Bornean exotic tree plantation: A long-term perspective'. Biological Conservation, 143(2), 399-407.

[129] Sodhi, N. S, Koh, L. P, \& Prawiradilaga, D. M. Darjono, Tinulele, I., Putra, D.D. and Tan, T.H.T. ((2004). Land use and conservation value for forest birds in Central Sulawesi (Indonesia)'. Biological Conservation, 122(4), 547-558.

[130] Sodhi, N. S, \& Brooks, B. W. (2006). Southeast Asian Biodiversity in Crisis. Cambridge: Cambridge University Press.

[131] Sodhi, N. S, Posa, M. R. C, Lee, T. M, Bickford, D, Koh, L. P, \& Brook, B. W. (2010). The state and conservation of Southeast Asian biodiversity'. Biodiversity Conservation, , 19(2), 317-328.

[132] Strassburg, B. B. N, Kelly, A, Balmford, A, Davies, R. G, Gibbs, H. K, Lovett, A, Miles, L, Orme, C. D. L, Price, J, Turner, R. K, \& Rodrigues, A. S. L. (2010). Global congruence of carbon storage and biodiversity in terrestrial ecosystems'. Conservation Letters, 3 (2), 98-105.

[133] Struebig, M, Kingston, T, Zubaid, A, Mold-adnan, A, \& Rossiter, S. J. (2008). Conservation value of forest fragments to Palaeotropical bats'. Biological Conservation, 141(8), 2112-2126.

[134] Struebig, M. J, Paoli, G, \& Meijaard, E. (2010). A reality check for designer biofuel landscapes'. Trends in Ecology and Evolution, 25(1), 7-8. 
[135] Taki, H, \& Kevan, P. G. (2007). Does habitat loss affect the communities of plants and insects equally in plant-pollinator interactions? Preliminary findings'. Biodiversity Conservation, 16 (11), 3147-3161.

[136] Tejeda-cruz, C, \& Sutherland, W. J. (2004). Bird Responses to Shade Coffee Production'. Animal Conservation , 7(2), 169-179.

[137] Tscharntke, T, Bommarco, R, Clough, Y, Crist, T. O, Kleijn, D, Rand, T. A, Tylianakis, J. M, Van Nouhuys, S, \& Vidal, S. (2007). Conservation biological control and enemy diversity on a landscape scale'. Biological Control, , 43(3), 294-309.

[138] Turner, I. M, \& Corlett, R. T. (1996). The conservation value of small isolated fragments of lowland tropical rainforest'. Trends in Ecology and Evolution, 11(8), 330-333.

[139] Turner, E. C, \& Foster, W. A. (2009). The impact of forest conversion to oil palm on arthropod abundance and biomass in Sabah, Malaysia'. Journal of Tropical Ecology, 25(1), 23-30.

[140] Waggoner, P. E. (1996). How much land can 10 billion people spare for nature?'. Daedalus, , 125, 73-93.

[141] Wallace, G. N, \& Barborak, J. and MacFarland, C.G. ((2005). Land-use planning and regulation in and around protected areas: a study of best practices and capacity building needs in Mexico and Central America'. Natureza y Conservacao , 3, 147-167.

[142] Warkentin, I. G, \& Greenberg, R. and Salgado Ortiz, J. ((1995). Songbird use of gallery woodlands in recently cleared and older settled landscapes of the Selva Lacandona, Chiapas, Mexico'. Conservation Biology, 9 (5), 1095-1106.

[143] Watts, K, Griffiths, M, Quine, C, Ray, D, \& Humphrey, J. W. (2005). Towards a woodland habitat network for Wales. Contract Science Report Countryside Council for Wales, Bangor.(686)

[144] Wells, K, Smales, L. R, Kalko, E. K. V, \& Pfeiffer, M. (2007). Impact of rain-forest logging on helminth assemblages in small mammals (Muridae, Tupaiidae) from Borneo'. Journal of Tropical Ecology, 23 (1), 35-43.

[145] Wild Asia ((2011). Bird Diversity Study in Sarawak Oil Palm Plantation'. Wild Asia Technical Support Programme. Available at: http://oilpalm.wildasia.org/1376/birddiversity-study-in-sarawak-oil-palm-plantation/Accessed 14 August 2012)

[146] WWF ((2012). Palm oil and biodiversity loss'. WWF Global. Available at http:// wwf.panda.org/what_we_do/footprint/agriculture/palm_oil/environmental_impacts/ biodversity_loss/Accessed 16 August 2012) 
